\title{
Agreement assessment between hemoglobin and hematocrit to detect anemia prevalence in children less than 5 years old
}

\author{
Avaliação da concordância entre hemoglobina e \\ hematócrito para detectar prevalência de anemia em \\ crianças menores de 5 anos
}

\author{
Gisela Soares Brunken¹, Giovanny Vinícius Araújo de França², \\ Ronir Raggio Luiz', Sophia Cornbluth Szarfarc ${ }^{5}$
}

\begin{abstract}
This study aimed to assess the extent of agreement between hemoglobin $(\mathrm{Hb})$ and hematocrit $(\mathrm{Ht})$, while also verifying whether anemia prevalence can be determined by hematocrit cut-off points. A hundred pairs of capillary $\mathrm{Hb}$ and $\mathrm{Ht}$ of children less than 5 years old were analyzed. The $\mathrm{Hb}$ and $\mathrm{Ht}$ concentrations were measured using HemoCue and microhematocrit centrifuge, respectively. The Bland and Altman's method was used to assess the agreement between 'observed $\mathrm{Hb}$ ' and 'Hb estimated through $\mathrm{Ht}^{\prime}(\mathrm{Hb}=\mathrm{Ht} / 3)$. The ROC curve was constructed based on the reference to anemia classification according to $\mathrm{Hb}$. The subjects were classified according to the status of anemia obtained through the $\mathrm{Ht}$, also evaluating the agreement regarding $\mathrm{Hb}$. The area under the ROC curve identified that $\mathrm{Ht}<35 \%$ correctly classified $85 \%$ of subjects with $\mathrm{Hb}<11.0 \mathrm{~g} / \mathrm{dL}$. However, the cut-off point of $<33 \%$ showed higher kappa $(\mathrm{k}=0.49$ against 0.41$)$ and higher relative agreement $(82 \%$ vs. $74 \%)$ compared to $\mathrm{Ht}<35 \%$. Our findings indicate that capillary $\mathrm{Hb}$ and $\mathrm{Ht}$ could be used either together or separately to assess the prevalence of anemia. Considering the need to identify iron deficiency anemia with a single indicator in population studies, the use of Ht would be simpler and cost-saving. Keywords: hematocrit; hemoglobin; reproducibility of results; child preschool; anemia, iron-deficiency.
\end{abstract}

\footnotetext{
Resumo

O objetivo deste estudo foi avaliar o grau de concordância entre a hemoglobina $(\mathrm{Hb})$ e o hematócrito $(\mathrm{Ht})$, para verificar se a prevalência de anemia pode ser determinada pelo hematócrito. Cem pares de $\mathrm{Hb}$ e Ht capilar de crianças menores de 5 anos de idade foram analisados. A concentração de $\mathrm{Ht}$ e $\mathrm{Hb}$ foi medida utilizando centrífuga para microhematócrito e HemoCue, respectivamente. A análise de Bland e Altman foi utilizada para avaliar as diferenças entre os valores observados de $\mathrm{Hb}$ e de $\mathrm{Hb}$ estimada através de hematócrito $(\mathrm{Hb}=\mathrm{Ht} / 3)$. A curva $\mathrm{ROC}$ foi calculada com referência à classificação de anemia ferropriva, a partir dos resultados de $\mathrm{Hb}$. Os indivíduos foram classificados de acordo com o estado de anemia a partir do $\mathrm{Ht}$, comparando com a avaliação obtida a partir da $\mathrm{Hb}$. A área sob a curva ROC permite identificar que $\mathrm{Ht}<35 \%$ corretamente classificava $85 \%$ dos indivíduos com $\mathrm{Hb}<11,0 \mathrm{~g} / \mathrm{dL}$. No entanto, o ponto de corte $\mathrm{Ht}<33 \%$ apresentou maior kappa $(\mathrm{k}=0,49$ contra 0,41$)$ e concordância relativa mais elevada ( $82 \%$ vs. $74 \%$ ) em comparação com $\mathrm{Ht}<35 \%$. A hemoglobina e o hematócrito capilar podem ser usados em conjunto ou separadamente para avaliar a prevalência de anemia. Considerando a necessidade de identificar a anemia ferropriva com um único indicador em estudos populacionais, a utilização do Ht seria mais simples e econômica.

Palavras-chave: hematócrito; hemoglobina; reprodutibilidade dos testes; pré-escolar; anemia ferropriva.

'Departamento de Saúde Coletiva, Universidade Federal de Mato Grosso (UFMT) - Cuiabá (MT), Brazil.

${ }^{2}$ Centro de Pesquisas Epidemiológicas, Universidade Federal de Pelotas (UFPEL) - Pelotas (RS), Brazil.

${ }^{3}$ MRC Epidemiology Unit, Institute of Metabolic Science, Addenbrooke's Hospital - Cambridge, UK.

${ }^{4}$ Instituto de Estudos em Saúde Coletiva, Universidade Federal do Rio de Janeiro (UFRJ) - Rio de Janeiro (RJ), Brazil.

${ }^{5}$ Faculdade de Saúde Pública, Universidade de São Paulo (USP) - São Paulo (SP), Brazil.

Study carried out at Federal University of Mato Grosso (UFMT) - Cuiabá (MT), Brazil.

Correspondence: Gisela Soares Brunken - Rua Buenos Aires, 726, apto 102, CEP: 78060-634 - Cuiabá (MT), Brazil - Email: brunken@terra.com.br

Financial support: none.

Conflict of interests: nothing to declare.
} 


\section{INTRODUCTION}

Iron deficiency anemia is the world's most prevalent nutritional deficiency, affecting several countries worldwide, with serious consequences for human health, social development and economy ${ }^{1}$. Its etiology is diverse and can be attributed to nutritional deficiencies of iron, folic acid, vitamin $\mathrm{A}, \mathrm{C}$ or $\mathrm{B}_{12}$, as well as numerous diseases, such as malaria, intestinal parasites, hemoglobinopathy. Iron deficiency has been identified as the main contributing factor to anemia, so that the terms "anemia" and "iron deficiency" are often treated as synonyms. As iron deficiency anemia is the most severe stage of the iron deficiency, it is estimated that there are about 2.5 times more individuals that are iron deficient than anemic ${ }^{2,3}$. Studies have shown that anemia persists over last decades at high levels, during infancy and childhood ${ }^{4,5}$.

Different from anemia driven by vitamin $\mathrm{B}_{12}$ or folic acid deficiency, iron deficiency anemia is microcytic and hypochromic. There are several well-described laboratory measurements to access and monitor the nutritional status of iron, but only hemoglobin and hematocrit are routinely performed in field trials ${ }^{6,7}$.

The hemoglobin concentration lower than $11 \mathrm{~g} / \mathrm{dL}$ indicates anemia, regardless the etiology ${ }^{2}$. Venous blood measurement is well standardized ${ }^{6,7}$, however practical issues limit its use in epidemiological studies. Therefore, $\mathrm{Hb}$ concentration is commonly measured in capillary blood, using an accurate point-of-care test such as the HemoCue (HemoCue AB, Angelholm, Sweden) ${ }^{8}$. Collecting a drop of blood using a finger stick, rather than collecting venous blood using a syringe, is a significant advantage in the field research. Moreover, it is fast, portable, shows directly the WHO anemia indicator and it is safer because it does not require aspiration or syringe. Unfortunately the cost of using HemoCue is high when compared to laboratory tests ${ }^{\mathrm{a}}$ and, once the seal is removed, the tubes with 50 micro cuvettes have a shelf life of only three months. The Agabê device ${ }^{\mathrm{b}}$ is also available since 2009, which is developed and produced in Brazil (M-Exa Biomedical Instrumentation). It allows dosing hemoglobin in a much more cost efficient manner. As the HemoCue device, it informs the hemoglobin concentration in capillary sample in real time, but requires dilution of the blood drop on the reagent, demanding cautious for treatment and evaluation of the sample in the field.

The hematocrit (or packed cell volume) is the percentage of volume occupied by red blood cells compared to the total blood volume. It is obtained using a centrifuge microhaematocrit, a simple and cost-saving approach ${ }^{\mathrm{c}}$, which is a portable and

At July 2014.

a HemoCue $=\mathrm{R} \$ 4,850.00$; Case with 200 microcuvettes $=\mathrm{R} \$ 880.00$ ( $\mathrm{R} \$ 4.40$ / microcuvette).

b Agabê $=$ R\$ 120.00 .

c Centrifug for microhematocrit, capacity for 24 capillary tubes, Centribio $=\mathrm{R} \$ 2,900.00$ practical equipment for use in field work. It requires a simple and short training period to operate, and a stable power source. It requires about $0.5 \mathrm{~mL}$ of blood, equivalent to a drop, extracted in a capillary tube, closed at one end and centrifuged ${ }^{6,7}$. As in portable hemoglobinometers (HemoCue and Agabê), it does not require transportation of samples and the results are released in a few minutes. The same method is used by blood banks to identify donors feasibility. One limitation is the need of a high centrifugal force to prevent a significant amount of plasma being trapped between the red blood cells. This can be eliminated by the use of a stable power source ${ }^{7}$.

The hematocrit below $33 \%$ is an acceptable indicator for evaluation and identification of anemic patients with hemoglobin in place $^{2}$. There is a standard conversion between the two measures $(\mathrm{Hb}=\mathrm{Ht} / 3)$ which is commonly used to define cut-off points for estimating the prevalence of anemia ${ }^{9}$. Health services has been using this indicator for anemia screening, since it is less expensive and more practical, but reliability studies are needed. In this study, we aimed to assess the agreement between hemoglobin and hematocrit capillary under field conditions in children less than 5 years old, in order to identify a cut-off point with adequate psychometric characteristics for the outcome of hematocrit sensitive to identify individuals with microcytic anemia. It is important to investigate the advantage of using the hematocrit instead of hemoglobin. In fact, it is not to say that one method is better than another, but knowing that the two are consistent and, judging by the hematocrit, has its validity.

\section{MATERIALS AND METHODS}

This is a cross sectional study carried out in 2008 including 100 children less than 5 years old who attended three public day care centers in the city of Cuiabá, a city located in the Center-West region of Brazil, state of Mato Grosso, with an estimated population of 569.830 inhabitants. A previous study showed high prevalence $(63 \%)$ of anemia among children aged less than 36 months in public day care centers of Cuiabá ${ }^{10}$.

Weight was measured on an electronic scale (capacity: $150 \mathrm{~kg}$; precision: $50 \mathrm{~g}$ ) and height using an anthropometric scale (precision: $0.5 \mathrm{~cm}$ ). Nutritional status was classified as: underweight - weight for age $<-2$ standard deviations (SD) of the WHO Child Growth Standards median ${ }^{11}$-; stunting - height for age $<-2 \mathrm{SD}$ - and overweight - weight-for-height $>+2 \mathrm{SD}$. The associations between presence of anemia with sex, age and nutritional status were investigated using the qui-squared test.

Samples of capillary hematocrit and hemoglobin were collected using the methodology recommended by the manual of the HemoCue equipment ${ }^{4}$. Participants were classified according to the status of anemia from hemoglobin concentrations, according to the cut-off point recommended by $\mathrm{WHO}^{2}$. Regarding the cut-off points, we applied international recommendations on 
the diagnosis and classification of anemia ${ }^{2}$, classifying as normal hemoglobin values lower than $11.0 \mathrm{~g} / \mathrm{dL}$ and hematocrit lower than $33 \%$. The prevalence of anemia was estimated according to nutritional status and age.

The Bland and Altman method ${ }^{12}$ was used to assess the agreement between the two estimates of anemia status 'hemoglobin observed' and 'estimated hemoglobin' ( $\mathrm{Hb}=\mathrm{Ht} / 3)$, estimating the $95 \%$ limits of agreement from the differences observed. The Receiver Operating Characteristic curve (ROC) was constructed in order to identify the hematocrit value that maximizes the sensitivity and specificity in screening for anemia, with reference to the classification obtained from the capillary hemoglobin, comparing the 'crude' and 'adjusted for age and sex' ROC area. Subjects were also classified according to the status of anemia from hematocrit, using the cut-off point proposed by $\mathrm{WHO}^{2}$ and identified from the ROC curve by calculating the kappa coefficient to verify the degree of agreement in relation to the classification by hemoglobin.
Analyses were performed using Stata, version 11.0. The study protocol was approved by the Ethics Committee in Research of Hospital Universitário Julio Muller, Universidade Federal do Mato Grosso.

\section{RESULTS}

The average age was 35 months (range 13-56) among the 100 children evaluated (53 girls), and the mean weight and height were similar to their median: $13.5 \mathrm{~kg}$ (median 13.6) and $91.6 \mathrm{~cm}$ (median 91.8). The mean concentrations of hemoglobin and hematocrit were $11.7 \mathrm{~g} / \mathrm{dL}$ (median 11.9) and $36.2 \%$ (median 36.0), respectively (Table 1). The presence of anemia was significantly associated only with age (Table 2 ).

The Bland and Altman plot (Figure 1) presents the differences between observed and estimated hemoglobin from hematocrit. The differences were inversely associated with the mean of measured and estimated $\mathrm{Hb}(\mathrm{r}=-0.445, \mathrm{p}<0.001)$, and the $95 \%$ limits of agreement were -3.645 to $2.959 \mathrm{~g} / \mathrm{dL}$.

Table 1. Sample description of 100 children less than 5 years old assessed in public nurseries. Cuiabá - Mato Grosso, 2008

\begin{tabular}{|c|c|c|c|c|c|}
\hline \multirow[b]{2}{*}{ Variables } & \multicolumn{5}{|c|}{ Descriptive Statistics } \\
\hline & $\mathbf{N}$ & Mean & $\begin{array}{l}\text { Standard } \\
\text { Deviation }\end{array}$ & Median & Range \\
\hline Age (months) & 91 & 35.1 & 11.3 & 34.2 & $13-56$ \\
\hline Weight for Height (scores z) & 100 & 0.23 & 0.91 & 0.20 & $-2.46-2.44$ \\
\hline Height for Age (scores z) & 91 & -0.53 & 1.17 & -0.47 & $-4.45-4.66$ \\
\hline Weight for Age (scores z) & 91 & -0.13 & 0.94 & -0.16 & $-2.62-2.68$ \\
\hline BMI for Age (scores z) & 91 & 0.28 & 0.96 & 0.23 & $-2.61-2.6$ \\
\hline Hemoglobin (g/dl) & 100 & 11.7 & 1.2 & 11.9 & 7.9-14.7 \\
\hline Hematocrit (\%) & 100 & 36.2 & 5.5 & 36.0 & $19.0-55.7$ \\
\hline
\end{tabular}

Table 2. Prevalence of anemia of 100 children less than 5 years old assessed in public nurseries, according to sex, age and nutritional status. Cuiabá - Mato Grosso, 2008

\begin{tabular}{|c|c|c|c|c|}
\hline \multirow{2}{*}{ Variable } & \multicolumn{3}{|c|}{ Prevalence of anaemia ${ }^{*}$} & \multirow{2}{*}{ p-value ${ }^{* *}$} \\
\hline & $\mathbf{N}$ & $\%$ & CI 95\% & \\
\hline Overall $(n=100)$ & 23 & 23.0 & $15.7-32.4$ & - \\
\hline \multicolumn{5}{|l|}{$\operatorname{Sex}(n=100)$} \\
\hline Male & 13 & 27.7 & $10.3-32.0$ & 0.297 \\
\hline Female & 10 & 18.9 & $16.6-42.4$ & \\
\hline \multicolumn{5}{|l|}{ Age $(n=91)$} \\
\hline$<24$ months & 8 & 47.1 & $24.7-70.6$ & 0.002 \\
\hline$\geq 24$ months & 10 & 13.5 & $7.3-23.6$ & \\
\hline \multicolumn{5}{|l|}{ Underweight $(\mathrm{n}=91)$} \\
\hline No & 16 & 18.4 & $11.5-28.1$ & 0.121 \\
\hline Yes & 2 & 50.0 & $9.2-90.8$ & \\
\hline \multicolumn{5}{|l|}{ Stunting $(\mathrm{n}=91)$} \\
\hline No & 16 & 19.1 & $11.9-29.1$ & 0.543 \\
\hline Yes & 2 & 28.6 & $6.2-70.7$ & \\
\hline \multicolumn{5}{|l|}{ Overweight $(\mathrm{n}=100)$} \\
\hline No & 21 & 21.9 & $14.6-31.4$ & 0.190 \\
\hline Yes & 2 & 50.0 & $9.2-90.8$ & \\
\hline
\end{tabular}

${ }^{*} \mathrm{Hb}<11 \mathrm{~g} / \mathrm{dL}$

${ }^{*}$ Pearson's chi-squared test 
The area under the ROC curve was high (85\%) and significant ( $p<0.001)$, so the hematocrit value below $35 \%$ seems to correctly identify $85 \%$ of hemoglobin below $11.0 \mathrm{~g} / \mathrm{dl}$ (Figure 2 ). This cut-off point (35\%) presents a sensitivity of $78.3 \%$ to identify children with $\mathrm{Hb}<11.0$ (actually anemic) and $72.5 \%$ of non-anemic (specificity) (Table 3). There were no differences among crude and adjusted curves for age and sex ( $p>0.05)$.

Table 3 compares the sensitivity and specificity in predicting hematocrit anemia according to the two cut-off points: $\mathrm{Ht}<33 \%{ }^{2}$ and $\mathrm{Ht}<35 \%$ (this study). The specificity was higher $(88.3 \%$

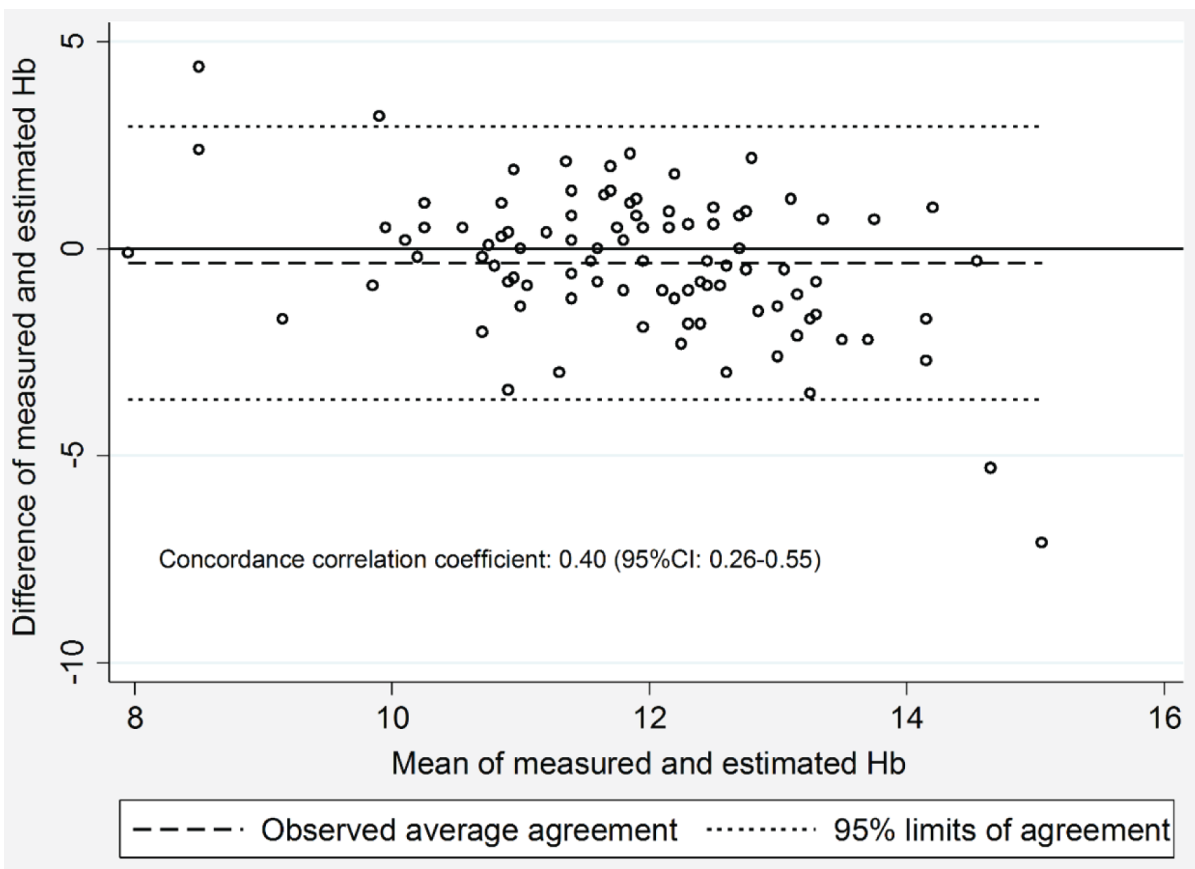

$r=-0.445, p<0.001$

Figure 1. Bland and Altman graph about the difference among hemoglobin measured and estimated from the hematocrit $(\mathrm{Hb}=\mathrm{Ht} / 3)$, by their average values in children less than 5 years old. Cuiabá - Mato Grosso, 2008. Diferences among crude and ajusted curves $\left(X^{2}=1.75 ;\right.$ Prob $\left.>X^{2}=0.1864\right)$

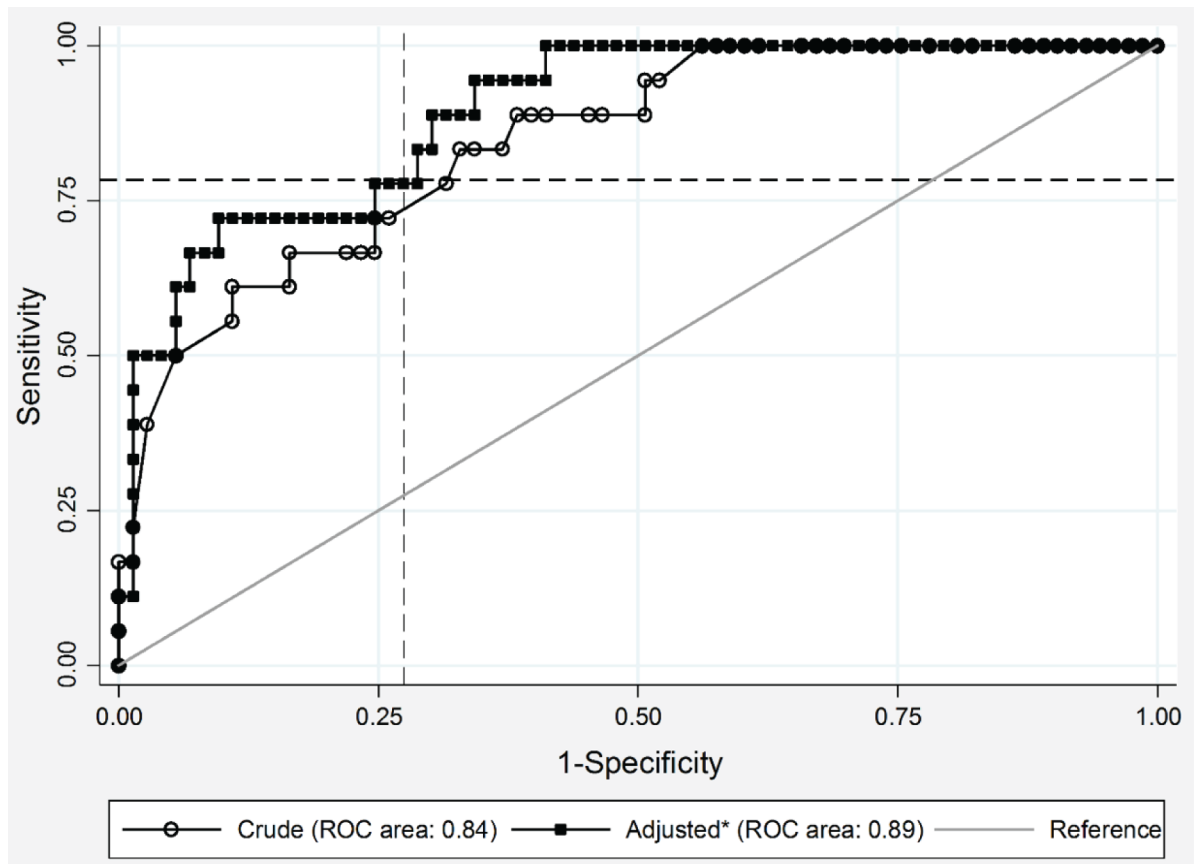

Diferences among crude and ajusted curves $\left(X^{2}=1.75 ;\right.$ Prob $\left.>X^{2}=0.1864\right)$

Figure 2. ROC curve of Hematocrit and diagnosis of anemia in children less than 5 years old, adjusted for age and sex. Cuiabá - Mato Grosso, 2008 
Table 3. Psychometric characteristics and agreement on the classification of anemia with hematocrit compared to that obtained by capillary hemoglobin in children less than 5 years old. Cuiabá - Mato Grosso, 2008

\begin{tabular}{|c|c|c|c|c|c|c|}
\hline \multirow[t]{2}{*}{ Anemia by Hematocrit } & \multicolumn{2}{|c|}{$\begin{array}{l}\text { Anemia by hemoglobin } \\
(\mathrm{Hb}<11 \mathrm{~g} / \mathrm{dl})\end{array}$} & \multirow{2}{*}{$\begin{array}{l}\text { Sensibility } \\
\text { (\%) }\end{array}$} & \multirow{2}{*}{$\begin{array}{l}\text { Specificity } \\
\text { (\%) }\end{array}$} & \multirow[t]{2}{*}{ Kappa } & \multirow{2}{*}{$\begin{array}{c}\text { Relative } \\
\text { Concordance } \\
(\%)\end{array}$} \\
\hline & Anemic & Not anemic & & & & \\
\hline $\mathrm{Ht}<33 \%$ & & & \multirow{3}{*}{60.9} & \multirow{3}{*}{88.3} & \multirow{3}{*}{0.49} & \multirow{3}{*}{82.0} \\
\hline Anemic & 14 & 9 & & & & \\
\hline Not anemic & 9 & 68 & & & & \\
\hline \multicolumn{7}{|l|}{$\mathrm{Ht}<35 \%$} \\
\hline Anemic & 18 & 21 & \multirow{2}{*}{78.3} & \multirow{2}{*}{72.5} & \multirow{2}{*}{0.41} & \multirow{2}{*}{74.0} \\
\hline Not anemic & 5 & 56 & & & & \\
\hline
\end{tabular}

$\mathrm{r}=-0.445, \mathrm{p}<0.001$

versus $72.5 \%$ ) for the cut-off point $<33 \%$, but the sensitivity was lower ( $60.9 \%$ versus 78.3$)$. The cut-off point $<33 \%$ showed a better but moderate kappa coefficient $(\mathrm{k}=0.49$ against $0.41)^{13}$. The relative agreement between the estimate of anemia $(\mathrm{Hb}<11.0 \mathrm{~g} / \mathrm{dl})$ using a cut-off of hematocrit $<33 \%$ was also better ( $82 \%$ vs. $74 \%$ ) when compared to the cut-off of $<35 \%$.

\section{DISCUSSION}

The cut-off for hematocrit $<33 \%$ had higher relative agreement and kappa coefficient in relation to the concentration of hemoglobin. It is important to remember that the relative agreement and kappa evaluate repeatability, but not necessarily validity. In addition, the kappa is strongly influenced by prevalence, as well as by positive and negative predictive values ${ }^{14}$. To assess validity, psychometric measurements - sensitivity and specificity - are more appropriate, verifying the best checking point that maximizes both ${ }^{15}$. Therefore, it is reasonable to use a cut-off $<35 \%$ due to the need for attracting more individuals at risk of deficiency. In addition, we found little variation on the relative agreement, less than $10 \%$, as well as a moderate kappa between the two cut-off points ${ }^{13}$.

Considering the Bland and Altman graphic (Figure 1), the bias seems to occur between proportional values close to the mean hemoglobin: 10 and $14 \mathrm{~g} / \mathrm{dL}$. That is, in a range close to the central values probably it will not occur medium estimation errors, in the case of using hematocrit to estimate the concentration of hemoglobin.

This study small sample size has limited power to predict the hemoglobin from hematocrit, but is sufficient to investigate the correlation between these two capillary measures. Surely the ideal is always to use more than two capillary measures, for better assessment of the nutritional status, as measured by the hematocrit and hemoglobin hypochromic microcytosis. However in field work, and also to track individuals and to have a rapid diagnosis, the health manager and the researcher often have to choose only one measure or instrument. In this case, the hematocrit seems to be a good option even if used alone.
Other researchers have used the hematocrit to estimate the prevalence of anemia in malaria endemic areas, reporting that the hematocrit underestimates the prevalence of anemia assessed by hemoglobin ${ }^{16,17}$. Graitcer et al. ${ }^{18}$ studied more than 10,000 pairs of examinations in children under 2 years of age and concluded that hemoglobin usually detects higher rates of anemia than hematocrit, as they identified more false negatives using the hematocrit $<33 \%$. The suggestion of this study to increase the cut-off of hematocrit $<33 \%$ to $<35 \%$ is one more argument to better assess its prevalence.

Quintó et al. ${ }^{19}$, studying paired values from almost 3,500 children under 5 years of age living in malaria-endemic areas in sub-Saharan Africa, observed that the $\mathrm{Hb} / \mathrm{Ht}$ ratio was not exactly $1 / 3$ and it varies during the first years of life. They also pointed out that the commonly assumed 'equivalent' cut-off points for anemia definition need to be re-evaluated. Flores-Torres et al. $^{20}$, studying 6,004 individuals, observed an overestimation of hemoglobin levels estimated from hematocrit levels and, therefore, an underestimation of the prevalence of anemia. This is another argument for adopting a higher cut-off point $(<35 \%)$ to estimate the presence of anemia from the hematocrit levels. Increasing the cut-off point from $33 \%$ to $35 \%$ would allow identifying more individuals at risk of iron deficiency.

The Brazilian Ministry of Health has implemented several programs to prevent and treat iron deficiency anemia. It is crucial to have fast and cost-saving approaches to estimate the prevalence of anemia, especially in Brazil where universal intervention are being used, such as supplementation and fortification of foods with iron ${ }^{21}$.

\section{CONCLUSION}

Hemoglobin and hematocrit capillary can be used together or separately to track and assess the prevalence of anemia. In Brazil, where the prevalence of iron deficiency anemia in children reaches epidemic proportions, Ht could be easily assessed in different settings, providing estimates of the prevalence of anemia and helping designing and implementing strategies to prevent and treat anemia. 


\section{REFERENCES}

1. World Health Organization. Worldwide prevalence of anemia 1993-2005: WHO global database on anemia. Geneve; 2008.

2. World Health Organization. Iron deficiency anemia: assessment, prevention and control. Geneve: UNICEF/UNU; 2001.

3. Batista Fo M, Souza AI, Bresani CC. Anemia como problema de saúde pública: uma realidade atual. Cien Saude Colet. 2008;13(6):1917-22. http:// dx.doi.org/10.1590/S1413-81232008000600027. PMid:18833369.

4. Kassebaum NJ, Jasrasaria R, Naghavi M, Wulf SK, Johns N, Lozano R, et al. A systematic analysis of global anemia burden from 1990 to 2010. Blood. 2014;123(5):615-24. http://dx.doi.org/10.1182/blood-2013-06-508325. PMid:24297872.

5. Granado FS, Augusto RA, Muniz PT, Cardoso MA. Anaemia and iron deficiency between 2003 and 2007 in Amazonian children under 2 years of age: trends and associated factors. Public Health Nutr. 2013;16(10):1751-9. http://dx.doi.org/10.1017/S1368980012005617. PMid:23369207.

6. International Nutritional Anemia Consultative Group. Measurements of iron status. Washington: ILSI Press; 1985.

7. World Health Organization. Assessing the iron status of populations. Geneve; 2007.

8. von Schenck H, Falkensson M, Lundberg B. Evaluation of "HemoCue", a new device for determining haemoglobin. Clin Chem. 1986;32(3):526-9. PMid:3948400.

9. Bain BJ, Bates I. Basic haematological techniques. In: Lewis SM, Bain BJ, Bates I. Practical hematology. 9th ed. Edinburgh: Churchill Livingstone; 2001. p. 19-46.

10. Brunken GS, Guimarães LV, Fisberg M. Anemia em crianças menores de 3 anos que freqüentam creches públicas em período integral. J. Pediatr. 2002; 78(1):50-6. http://dx.doi.org/10.2223/JPED.664.

11. World Health Organization. Nutritional Landscape Information System (NLIS) country profile indicators: interpretation guide. Geneve; 2010.

12. Bland JM, Altman DG. Statistical methods for assessing agreement between two methods of clinical measurements. Lancet. 1986;1(8476):307-10. http:// dx.doi.org/10.1016/S0140-6736(86)90837-8. PMid:2868172.
13. Altman DG. Practical statistics for medical research. London: Chapman \& Hill; 1991

14. Hoehler FK. Bias and prevalence effects on kappa viewed in terms of sensitivity and sensitivity and specificity. J Clin Epidemiol. 2000;53(5):499503. http://dx.doi.org/10.1016/S0895-4356(99)00174-2. PMid:10812322.

15. Fletcher RH, Fletcher SW. Epidemiologia clínica: elementos essenciais. São Paulo: Art Med; 2006. 188 p.

16. Carneiro IA, Drakeley CJ, Owusu-Agyei S, Mmbando B, Chandramohan D. Haemoglobin and haematocrit: is the threefold conversion valid for assessing anaemia in malaria-endemic settings? Malar J. 2007;6(1):67-71. http://dx.doi.org/10.1186/1475-2875-6-67. PMid:17519019.

17. Rodríguez-Morales AJ, Sánchez E, Arria M, Vargas M, Piccolo C, Colina $\mathrm{R}$, et al. Haemoglobin and haematocrit: the threefold conversion is also non valid for assessing anaemia in Plasmodium vivax malaria-endemic settings. Malar J. 2007;6(1):166-9. http://dx.doi.org/10.1186/1475-28756-166. PMid:18086306.

18. Graitcer PL, Goldsby JB, Nichaman MZ. Hemoglobins and hematocrits: are they equally sensitive in detecting anemias? Am J Clin Nutr. 1981;34(1):614. PMid:7446459.

19. Quintó L, Aponte JJ, Menéndez C, Sacarlal J, Aide P, Espasa M, et al. Relationship between haemoglobin and haematocrit in the definition of anaemia. Trop Med Int Health. 2006;11(8):1295-302. http://dx.doi. org/10.1111/j.1365-3156.2006.01679.x. PMid:16903892.

20. Flores-Torres J, Echeverría-Ortega M, Arria-Bohorquez M, Hidalgo G, Albano-Ramos C, Sanz R, et al. Diferencias entre la hemoglobina observada y estimada por hematocrito y su importancia en el diagnóstico de anemia en población costera Venezolana: análisis del segundo estudio nacional de crecimiento y desarrollo humano (SENACREDH). Rev Peru Med Exp Salud Publica. 2011;28(1):47-53. http://dx.doi.org/10.1590/S172646342011000100008. PMid:21537769.

21. Szarfarc SC. Políticas públicas para o controle da anemia ferropriva. Rev Bras Hematol Hemoter. 2010;32(Suppl 2):2-7. http://dx.doi.org/10.1590/ S1516-84842010005000065.

Received on: Oct. 09, 2015 Accepted on: Feb. 01, 2016 